\section{BRAZIULIAN JOURNAL}

OF MEDICAL AND BIOLOGICAL RLSH.ARCH

www.bjournal.com.br
ISSN 0100-879X

Volume 43 (01) 1-123 January 2010

BIOMEDICAL SCIENCES

AND

CLINICAL INVESTIGATION

Braz J Med Biol Res, J anuary 2010, Volume 43(1) 36-42

Mechanism of the transforming growth factor- $\beta$ induction of fibronectin expression in hepatic stem-like cells

W. Cui, H.B. Jin and Z.W. Li

The Brazilian Journal of Medical and Biological Research is partially financed by
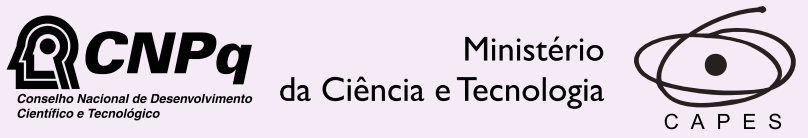

Ministério da Educação

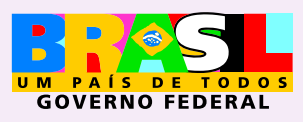

Institutional Sponsors 


\title{
Mechanism of the transforming growth factor- $\beta$ induction of fibronectin expression in hepatic stem-like cells
}

\author{
W. Cui ${ }^{1,2}$, H.B. Jin ${ }^{1}$ and Z.W. Li ${ }^{1}$ \\ ${ }^{1}$ Department of Infectious Diseases, Shengjing Hospital Affiliated to \\ China Medical University, Shenyang, China \\ 2Department of Pharmacology, Shenyang Pharmaceutical University College of Life Science \\ and Biopharmaceutical, Shenyang, China
}

\begin{abstract}
Transforming growth factor- $\beta 1$ (TGF- $\beta 1$ ) plays an important role in the fibrogenic process in the liver. The aim of the present study was to explore the action of TGF- $\beta 1$ on fibronectin expression in rat hepatic stem-like cells and the underlying mechanisms. The level of fibronectin expression was determined in hepatic stem-like cells (WB cells) before and after TGF- $\beta 1$ stimulation by RT-PCR and Western blot methods. Using immunogold transmission electron microscopy and the Western blot method, we observed the result of the expression and the distribution of cAMP, phosphorylated Smad3 and Smad7 before and after TGF- $\beta 1$ treatment. The levels of fibronectin expression in both mRNA and protein increased 4- to 5-fold after TGF- $\beta 1$ stimulation, reaching an optimum level after $8 \mathrm{~h}$ and then gradually falling back. Similarly, TGF- $\beta 1$ stimulation resulted in an increase of cAMP in WB cells, peaking at $8 \mathrm{~h}$. After treatment with TGF- $\beta 1$ for $24 \mathrm{~h}$, the expression of cAMP gradually decreased. In addition, we found that TGF- $\beta 1$ treatment also contributed to the increased expression and to changes in cellular distribution of phosphorylated Smad3 (translocation from the cytoplasm to the nucleus) and Smad7 (translocation from the nucleus to the cytoplasm) in WB cells. The present study demonstrates that TGF- $\beta$ is involved in the fibrogenic process in hepatic stem cells through up-regulation of fibronectin expression, and the mechanisms underlying this process may be associated with the activation of cAMP and Smad pathways.
\end{abstract}

Key words: TGF- $\beta$; Fibronectin; Fibrogenesis; Hepatic stem cell; cAMP; Smad

\section{Introduction}

The remarkable regenerative capacity of the human liver is usually provided by the presence of hepatocytes and cholangiocytes (1). Sometimes, when the ability of hepatocytes to divide and replace damaged tissue is compromised, bipotent progenitor cells will be activated, giving rise to both new hepatocytes and biliary epithelial cells.

While the function and nomenclature of stem cells located in the liver is still an area of dispute, it is nevertheless generally agreed that liver oval cells are 'stem-like' cells descending from a population of progenitor cells involved in liver regeneration (2,3). More importantly, recent reports hint that hepatic stellate cell (HSC) activation may contribute to hepatic stem cell behavior (4). Thus, 'stem-like' cells in the liver may play a significant role in hepatic fibrogenesis.

It is firmly established that the fibrogenic process in the liver is prominently regulated by transforming growth factor- $\beta 1$ (TGF- $\beta 1$ ) (5). TGF- $\beta 1$ signaling is initiated following ligand binding to the TGF- $\beta$ type II receptor, T $\beta$ R-II. This allows the recruitment of the TGF- $\beta$ type I receptor, $T \beta R-I$, into a heteromeric complex, resulting in transphosphorylation of T $\beta R$-I by T $\beta R$-II. Following phosphorylation of Smad2 or Smad3 by the activated T $\beta R$-I, a heteromeric complex is formed with Smad4, resulting in translocation of the complex to the nucleus where the complex can directly or indirectly, by interactions with other transcription factors, regulate the involvement of gene transcription in fibrosis (5-7). Besides HSC, which are induced by TGF- $\beta$ to transdifferentiate to myofibroblasts and to synthesize an array of extracellular matrix molecules such as fibronectin (FN), hepatocytes are also increasingly recognized as an important cell type involved in the TGF- $\beta$-regulated fibrogenic process $(6,7)$. However, it is still unclear how TGF- $\beta$

Correspondence: Z.W. Li, Department of Infectious Diseases, Shengjing Hospital Affiliated to China Medical University, Shenyang, 110004 China. Fax: +86-024-2389-2617. E-mail: lizw@sj-hospital.org

Received June 26, 2009. Accepted November 4, 2009. Available online November 23, 2009. Published January 11, 2010. 
regulates the fibrogenic process in hepatic stem cells. The rat liver epithelial stem-like WB-F344 cell line, isolated from the liver of an adult male Fischer 344 rat, is considered to be an in vitro model of bipotent oval cells since it shares their phenotype $(8,9)$. In the present study, using the WBF344 cell line, we demonstrate that TGF- $\beta$ is involved in the fibrogenic process by regulating $F N$ in hepatic stem cells, and show that the CAMP and Smad pathways may be required for this process.

\section{Material and Methods}

\section{Cell culture}

The rat hepatic stem-like cell line WB-F344 was generously provided by Dr. Han Rui (Chinese Academy of Medical Sciences, Beijing) and maintained in Dulbecco's modified Eagle's medium (Life Technologies, Inc., USA) supplemented with $10 \%$ FCS, $200 \mathrm{mM}$ glutamine, and $0.05 \%$ gentamicin.

\section{Western blot analysis}

Cells were treated with $5 \mathrm{ng} / \mathrm{mL}$ TGF- $\beta 1$ for various times $(0,2,4,8,12$, and $24 \mathrm{~h})$ followed by incubation in lysis buffer on ice for $30 \mathrm{~min}$. Denatured proteins were then separated by SDS-PAGE, transferred to PVDF membranes, and incubated at room temperature for $1 \mathrm{~h}$ or at $4^{\circ} \mathrm{C}$ overnight with a rabbit-anti-rat FN antibody $(1: 100$; Santa Cruz Biotechnology, USA), or a rabbit monoclonal anti-rat P-Smad3 antibody (1:500; Santa Cruz Biotechnology), or a rabbit monoclonal anti-rat Smad7 antibody (1:500; Santa Cruz Biotechnology). After washing in Trisbuffered saline with $0.05 \%$ Tween 20 (TBS-Tween), the blots were reacted with alkaline phosphorylated-linked goat anti-rabbit IgG (1:500) at room temperature for 2 h. Pre-stained molecular mass was used to estimate the position of various proteins on the gel. Blots were stripped and incubated with a monoclonal antibody against $\beta$-actin (1:1000; Santa Cruz Biotechnology) to confirm that an equal amount of protein was loaded. The target was then stained with 5-bromo-4-chloro-indolyl phosphate/ nitroblue tetrazodium and the bands were analyzed with the Tanon-Gis system.

\section{RNA extraction and reverse transcription-PCR}

After treating WB cells with TGF- $\beta 1(5 \mathrm{ng} / \mathrm{mL})$ for 0,4 , 8 , and $24 \mathrm{~h}$, total RNA was extracted from the cells with the TRIzol Reagent (Invitrogen-Life Technologies, Inc., USA) according to manufacturer instructions. RNA was reversetranscribed with Superscript II Transcriptase (Invitrogen-Life Technologies, Inc.) in the presence of oligo-dT and random primers. Primer sequences and PCR conditions are shown in Table 1. PCR products were analyzed with $1 \%$ agarose gels stained with ethidium bromide.

\section{Immunogold transmission electron microscopy}

After treatment with TGF- $\beta 1$, WB cells were first collected and prefixed with $2.5 \%$ glutaraldehyde in PBS for 120 min, washed three times with 0.1 M PBS, postfixed in $1 \%$ osmium tetroxide fixative (Millonigs buffer, $\mathrm{pH} 7.3$ ) for $30 \mathrm{~min}$ and dehydrated in an ethanol series. They were then saturated and embedded in epoxy resin (Emitech, Ashford, Kent, UK) overnight. The cell blocks were subsequently cut on a Leica Ultracut machine to an ultrathin thickness of $70 \mathrm{~nm}$. The ultrathin sections were loaded on nickel nets, which were then blocked for 30 min with $1 \%$ bovine serum albumin (BSA) and washed with $0.1 \mathrm{M}$ PBS. The primary antibodies (rabbit monoclonal anti-rat cAMP, 1:80; P-Smad3, 1:80; Smad7, 1:60) were incubated in incubation buffer [1\% goat serum (British Biocell International, UK), $0.1 \%$ Tween 20 (British Biocell International) and 1\% BSA (British Biocell International) in PBS, adjusted to $\mathrm{pH} 8.2$ by the addition of sodium hydroxide and hydrochloric acid] for $2 \mathrm{~h}$, and then washed twice with the incubation buffer. Next, the cells were incubated with the secondary gold-labelled antibodies (gold-conjugated goat anti-rabbit IgG 1:25, 6 $\mathrm{nm}$ ) in the incubating buffer (as above) for $1.5 \mathrm{~h}$ and then washed three times in PBS. Finally, the ultrathin sections were stained with uranyl acetate and areas were selected for viewing by transmission electron microscopy (TEM).

\section{Results}

\section{TGF- $\beta$ induces fibronectin expression in WB cells}

In order to investigate the role of TGF- $\beta$ in the fibrogenic process in hepatic stem cells, we first detected the expres-

Table 1. Primers, amplicon size, and protocol details for PCR.

\begin{tabular}{|c|c|c|c|c|c|}
\hline & Primers ( $5^{\prime}$ to $3^{\prime}$ ) & Size (bp) & $\mathrm{T}\left({ }^{\circ} \mathrm{C}\right)$ & Extension time (s) & No. of cycles \\
\hline \multirow[t]{2}{*}{ Fibronectin } & F: GTGTCCTCCTTCCATCTTC & 290 & 55 & 60 & 35 \\
\hline & R: CAGACTGTCGGTACTCACG & & & & \\
\hline \multirow[t]{2}{*}{$\beta$-actin } & F: CCACACAGATGACTTGCGCTCAGG & 690 & 55 & 60 & 35 \\
\hline & R: CACCCTGTGCTGCTCACCGAGGCC & & & & \\
\hline
\end{tabular}

$\mathrm{F}=$ forward $\mathrm{R}=$ reverse $; \mathrm{T}\left({ }^{\circ} \mathrm{C}\right)=$ annealing temperature. 
sion of $\mathrm{FN}$, an extracellular matrix glycoprotein, at 0, 4, 8, and $24 \mathrm{~h}$ after TGF- $\beta$ stimulation by Western blot analysis. The results showed that $F N$ levels increased gradually and reached their optimum yield (5-fold increasing) after $8 \mathrm{~h}$, decreasing thereafter (Figure 1A). Next, to ascertain the up-regulation of FN transcription induced by TGF- $\beta$, we performed RT-PCR. The results showed a pattern similar to that of the immunoblot data (Figure 1B). When combined, the results demonstrated that TGF- $\beta 1$ stimulation can promote FN expression at both the levels of mRNA and protein.

\section{Involvement of Smad signaling in TGF- $\beta$-induced up-regulation of FN}

To determine whether stem cells signal in response to TGF- $\beta$ and to explore the potential mechanism of FN up-regulation, we examined Smad signaling using immunogold TEM and the Western blot method. The immunogold TEM data showed that, after TGF- $\beta 1$ treatment, WB cells exhibited a substantial increase in phospho-Smad3 at $4 \mathrm{~h}$ (Figure 2B), especially in the nucleus, indicating that stem cells contain sufficient quantities of receptors and Smads to signal in response to TGF- $\beta$. Smad3 phosphorylation peaked in WB cells at $8 \mathrm{~h}$, and began to decrease after $24 \mathrm{~h}$ (Figure 2C,D). The Western blot results showed a pattern similar to that of immunogold TEM data (Figure 3). The phospho-Smad3 content increased within the initial $2 \mathrm{~h}$ following TGF- $\beta$ stimulation and then fell to baseline by 24 h. In addition, we also observed alteration of Smad7 after TGF- $\beta$ stimulation in WB cells. There was low expression of Smad7 in WB cells before TGF- $\beta$ treatment (Figure 4A). The cytoplasmic expression of Smad7 was increased in WB cells after TGF- $\beta$ treatment for $4 \mathrm{~h}$ (Figure 4B). Smad7 began to diminish in WB cells at $24 \mathrm{~h}$ (Figure 4D). To confirm the data described above, we performed a Western blot. The content of Smad7 increased within the initial $4 \mathrm{~h}$ following TGF- $\beta$ stimulation and then fell by $24 \mathrm{~h}$, in agreement with the results of immunogold TEM (Figure 3 ).

\section{cAMP involvement in TGF- $\beta$-induced up-regulation of FN}

CAMP is a second messenger that is important in many biological processes. To determine whether cAMP is involved in the FN up-regulation induced by TGF- $\beta$, we determined cAMP expression using immunogold TEM. As shown in Figure 5A, there was low expression of cAMP in the cytoplasm and nucleus of WB cells before TGF- $\beta 1$ treatment. In contrast, when WB cells were exposed to TGF- $\beta 1$ for $4 \mathrm{~h}$, the expressions of cAMP in cytoplasm and nucleus increased significantly (Figure $5 B$ ) and peaked after $8 \mathrm{~h}$, especially in the cytoplasm (Figure 5C). After treatment with TGF- $\beta 1$ for $24 \mathrm{~h}$, the expression of cAMP gradually decreased in WB cells (Figure 5D). The alterations of CAMP induced by TGF- $\beta 1$ in WB cells had a pattern similar to that of FN.

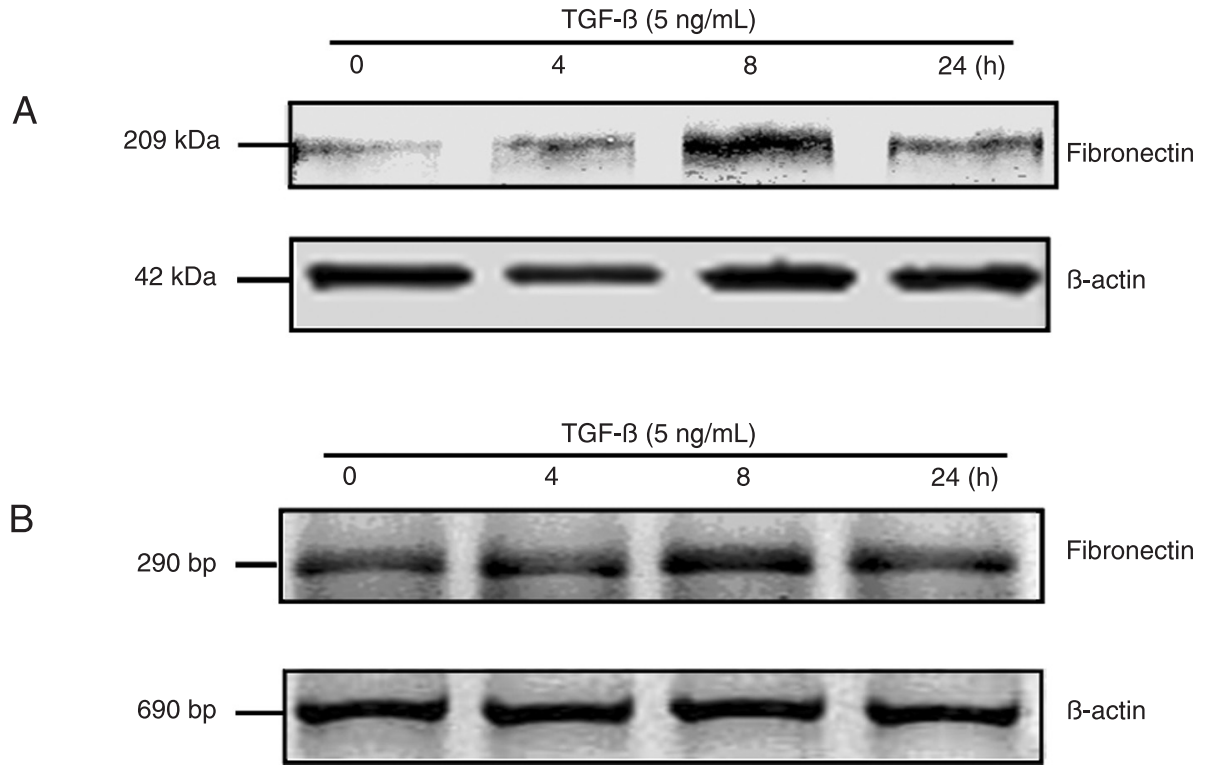

Figure 1. Effects of stimulation with transforming growth factor-beta (TGF- $\beta$ ) for various times on the expression of fibronectin (FN) in hepatic stem-like cells. $A$, Immunoblot analysis of FN protein. FN levels increased at $4 \mathrm{~h}$, reached a peak near $8 \mathrm{~h}$, and decreased after $24 \mathrm{~h} . \mathrm{B}, \mathrm{RT}$-PCR analysis of the fibronectin gene. The target protein was stained with 5-bromo-4-chloro-indolyl phosphate/nitroblue tetrazodium. PCR products were analyzed with $1 \%$ agarose gels stained with ethidium bromide. $\beta$-actin was used to normalize protein and mRNA levels. 


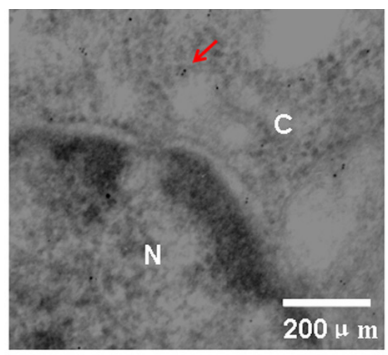

A

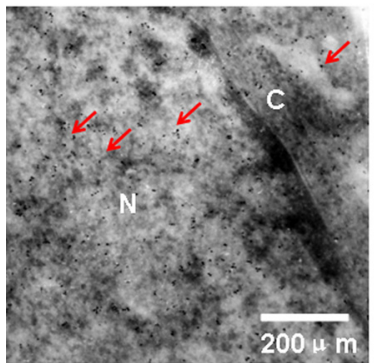

C

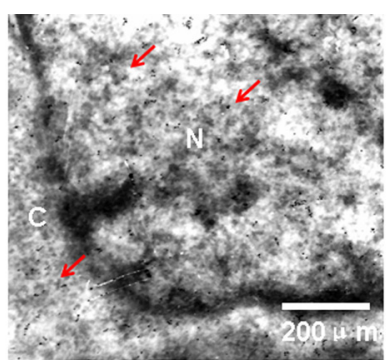

B

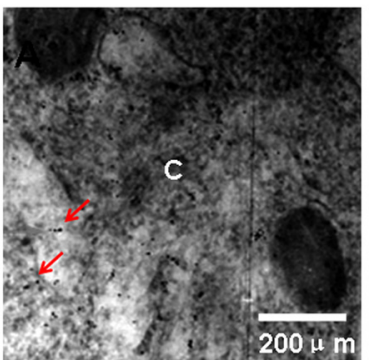

D

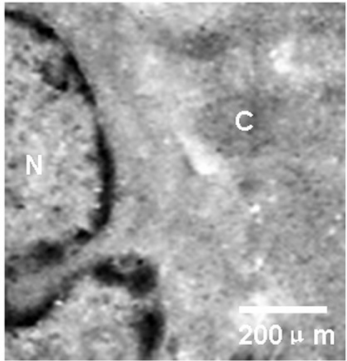

E

Figure 2. Electron micrographs of phosphorylated Smad3 expression and cellular distribution before and after stimulation with transforming growth factor-beta (TGF- $\beta$ ) in hepatic stem-like cells. $A$, Before TGF- $\beta$ stimulation, weak nuclear and cytoplasmic staining. $B$, TGF- $\beta$ stimulation for $4 \mathrm{~h}$, strong nuclear staining with medium cytoplasm staining. $C$, TGF- $\beta$ stimulation for $8 \mathrm{~h}$, strong nuclear staining with medium cytoplasm staining. $D$, TGF- $\beta$ stimulation for $24 \mathrm{~h}$, with weak cytoplasm staining. $E$, Negative control, negative nuclear and cytoplasmic staining. The primary antibody of rabbit monoclonal anti-rat P-Smad3 was diluted eighty times, and the secondary antibody of goat anti-rabbit IgG $(6 \mathrm{~nm})$ was diluted twenty-five times. Red arrows indicate positive staining. Magnification: $4000 X$. $N=$ nucleus; $C$ = cytoplasm.

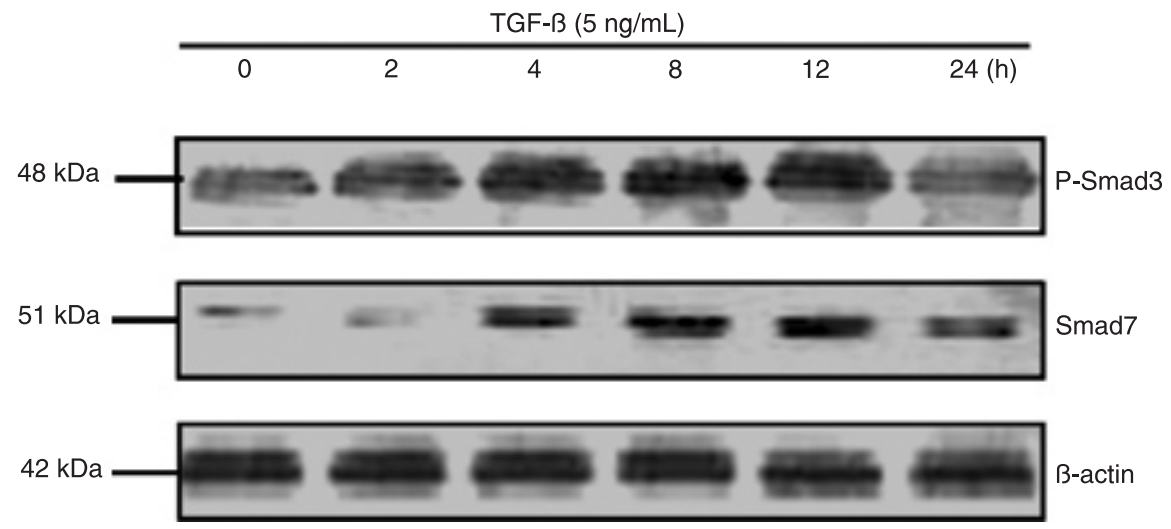

Figure 3. Effects of stimulation with transforming growth factor-beta (TGF- $\beta$ ) for various times on the expression of phosphorylated Smad3 and Smad7 in hepatic stem-like cells determined by immunoblot. For phosphorylated Smad3, the content increased within the initial $2 \mathrm{~h}$ following TGF- $\beta$ stimulation and then fell to baseline by $24 \mathrm{~h}$. For Smad7, the expression level increased within the initial 4 $\mathrm{h}$ following TGF- $\beta$ stimulation and then fell by $24 \mathrm{~h}$. The primary antibodies of rabbit monoclonal anti-rat P-Smad3 and anti-rat-Smad7 were diluted five hundred times, and the secondary antibodies of monoclonal antibody against $\beta$-actin was diluted one thousand times. $\beta$-actin was used to normalize protein levels. 


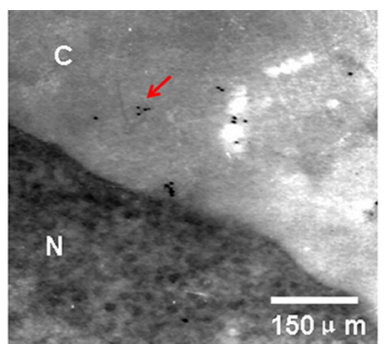

A

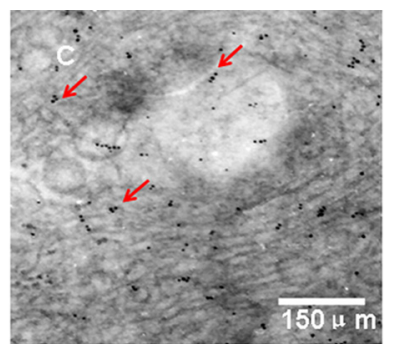

B

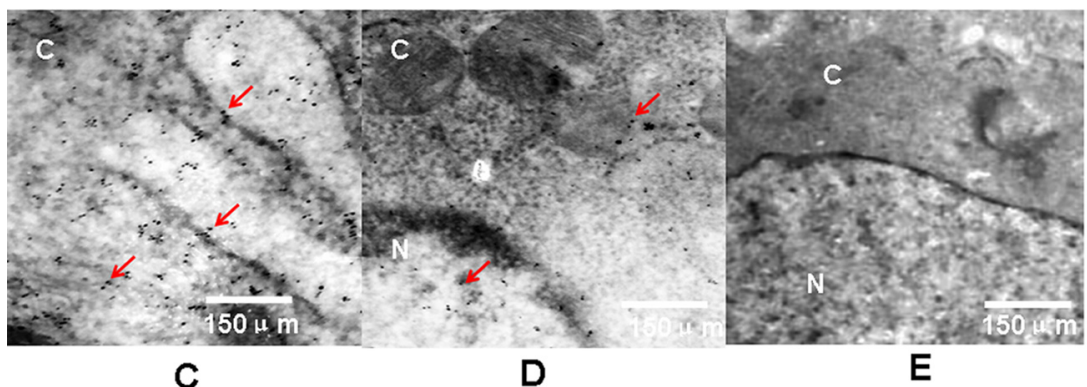

C

D

E

Figure 4. Electron micrographs of Smad7 expression and cellular distribution before and after stimulation with transforming growth factor-beta (TGF- $\beta$ ) in hepatic stem-like cells. $A$, Before TGF- $\beta$ stimulation, weak nuclear and cytoplasm staining. $B$, TGF- $\beta$ stimulation for $4 \mathrm{~h}$, strong cytoplasm staining. $C$, TGF- $\beta$ stimulation for $8 \mathrm{~h}$, strong cytoplasm staining. $D$, TGF- $\beta$ stimulation for $24 \mathrm{~h}$, weak nuclear and cytoplasm staining. $E$, Negative control, negative nuclear and cytoplasm staining. The primary antibody of rabbit monoclonal antirat Smad7 was diluted sixty times, and the secondary antibody of goat anti-rabbit lgG $(6 \mathrm{~nm})$ was diluted twenty-five times. Red arrows indicate positive staining. Magnification: 4000X. $\mathrm{N}=$ nucleus; $\mathrm{C}=$ cytoplasm.

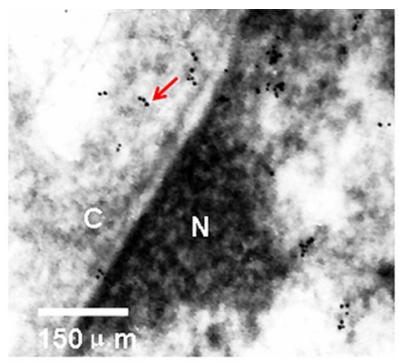

A

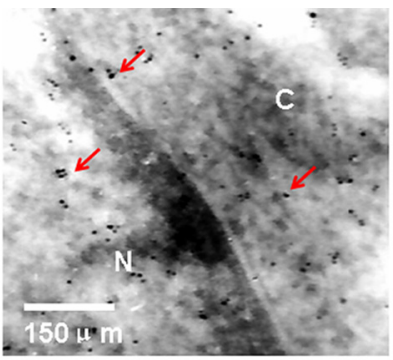

B

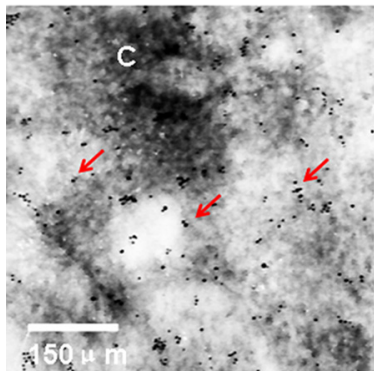

C

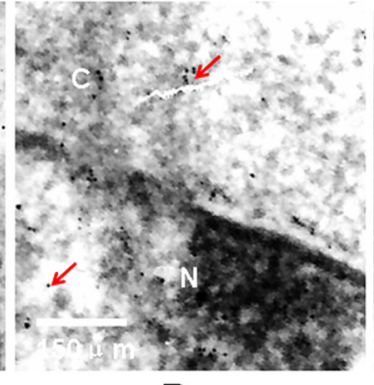

D

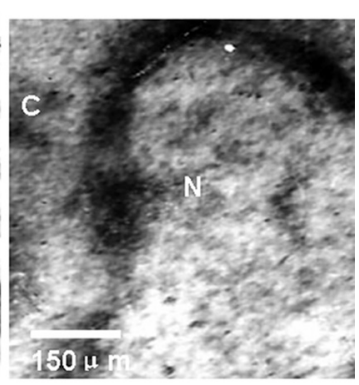

E

Figure 5. Electron micrographs of CAMP expression and cellular distribution before and after stimulation with transforming growth factor-beta (TGF- $\beta$ ) in hepatic stem-like cells. $A$, Before TGF- $\beta$ stimulation, weak nuclear and cytoplasm staining. $B$, TGF- $\beta$ stimulation for $4 \mathrm{~h}$, middle cytoplasm and nuclear staining. $C$, TGF- $\beta$ stimulation for $8 \mathrm{~h}$, strong cytoplasm staining. $D$, TGF- $\beta$ stimulation for $24 \mathrm{~h}$, weak nuclear and cytoplasm staining. $E$, Negative control, negative nuclear and cytoplasmic staining. The primary antibody of rabbit monoclonal anti-rat cAMP was diluted eighty times, and the secondary antibody of goat anti-rabbit lgG (6 nm) was diluted twenty-five times. Red arrows indicate positive staining. Magnification: 4000X. N = nucleus; C = cytoplasm. 


\section{Discussion}

Coordinated regulation of the production and turnover of components of the extracellular matrix (ECM) is essential for normal tissue homeostasis. The composition of the ECM can influence cell growth, state of differentiation and specific gene induction. FN, a major component of the ECM, plays an important role during development and wound healing by promoting cell adhesion, migration and cytoskeletal organization $(10,11)$. Overproduction of matrix components including $\mathrm{FN}$ is the main pathological finding in tissue fibrosis (12). Decreased FN production, however, is often observed following oncogenic transformation, leading to decreased adhesion and increased metastatic potential (11). TGF- $\beta$, which is released by degranulating platelets at a wound site, has been shown to potently induce FN expression at both the mRNA and protein levels $(5,13,14)$.

Recent research has shown that TGF- $\beta$ induces liver fibrosis by promoting FN expression. Ha et al. (15) reported that high glucose levels may increase $\mathrm{FN}$ expression in peritoneal mesothelial cells, leading to ECM deposition (15). Kitamura and Ninomiya (16) showed that TGF- $\beta 1$ causes liver fibrosis by promoting Smad $2 / 3,4$, and 7 expression in HSC. Schnur et al. (17) used transgenic mice to study the relationship between TGF- $\beta$ and liver fibrosis and proved that TGF- $\beta$ is somehow related to liver fibrosis. These studies demonstrate that HSC and hepatocytes are the major cells which produce ECM including FN. TGF- $\beta$ causes HSC and hepatocytes to produce $\mathrm{FN}$ and, as a result, leads to liver fibrosis. But it is not known whether TGF- $\beta$ can cause hepatic stem cells to express FN.

Here, we used TGF- $\beta$ to stimulate hepatic stem-like cells in vitro and measured $\mathrm{FN}$ protein and mRNA expression at different intervals after exposure to TGF- $\beta 1$. Our results indicated that the expression of $F N$ increased gradually and peaked at $8 \mathrm{~h}$ after TGF- $\beta$ exposure. It is suggested that TGF- $\beta$ can cause ECM deposition by promoting not only HSC and hepatocytes, but also hepatic stem cells during the process of liver fibrosis.

In the presence of the TGF- $\beta$ ligand, the receptoractivated Smads (R-Smads), Smads2 and 3, are phosphorylated directly by the TGF- $\beta$ receptor I kinase, bind to the common mediator Smad, Smad4, and are translocated into the nucleus $(6,7)$. In a recent experiment using microarrays to compare gene expression profiles of fibroblasts taken from adult Smad3 ${ }^{-/-}$and Smad3 $3^{+/+}$mice, TGF- $\beta$ did not induce transcription in Smad3//- fibroblasts (18). Thus, in adult fibroblasts Smad3 is required for TGF- $\beta$-induced gene expression. On the basis of these findings, we measured the expression levels and cellular distribution of phosphorylated Smad3 to identify the mechanism underlying the TGF- $\beta$-induced up-regulation of FN. We observed that WB cells presented a substantial increase in phospho-Smad3 levels after $4 \mathrm{~h}$, peaking at $8 \mathrm{~h}$, before decreasing after 24 h. These results suggest that phospho-Smad3 might be involved in the TGF- $\beta$-induced up-regulation of FN. Zhao et al. (19) reported that TGF- $\beta$ induced-phospho-Smad3 reached a peak at $1.5 \mathrm{~h}$ and then quickly fell by $3 \mathrm{~h}$ in HSC. Compared with these data, our result is relatively late and persistent, indicating that the duration of response to TGF- $\beta$ is cell-type dependent.

In normal cells, TGF- $\beta$ directly stimulates the transcription of inhibitory Smad7. Thus, Smad7 induction serves as a critical intracellular "brake" of TGF- $\beta$-induced responses. The physiologic importance of this Smad7-mediated autoinhibitory feedback loop is highlighted by recent observations with cultured cells in in vivo animal models. For example, tumor necrosis factor- $\alpha$ (TNF- $\alpha$ )-induced abrogation of TGF- $\beta$-dependent profibrotic responses was linked to the induction of endogenous Smad7 (20). On the other hand, defective Smad7 induction is implicated in the exaggerated TGF- $\beta$ responsiveness characteristic of hepatic cells and myofibroblasts from chronically injured livers $(21,22)$. In the present study, we observed that the expression of Smad7 began to increase after TGF- $\beta$ treatment for $4 \mathrm{~h}$. These data agree well with previous results obtained for skin fibroblasts (23). In addition, our result showed an obvious Smad7 translocation from nucleus to cytoplasm after treatment with TGF- $\beta$ for $4 \mathrm{~h}$. In fact, Smad7 has been shown to inhibit TGF- $\beta$ signaling by associating with the type I receptor and thereby interfering with Smad2/3 phosphorylation by the activated receptor complex in the cytoplasm $(6,7)$. Thus, it is possible that the elevated levels of Smad7 in the cytoplasm of stem cells provide a means to inhibit the signaling response to the ligand, which can prevent the phosphorylation and translocation to the nucleus of Smad2/3, and consequently inhibit the TGF- $\beta$-induced expression of FN. This hypothesis is supported by the finding of the alteration process of phospho-Smad3 and Smad7 induced by TGF- $\beta$ in WB cells.

In order to determine the mechanism underlying this response to TGF- $\beta$, we also examined the levels of cAMP in hepatic stem-like cells. cAMP is a second messenger that has been implicated as a modulator of cell proliferation and cell growth in several fibroblastic cell types (24). Recently, it was demonstrated that increased cAMP levels inhibit cardiac myofibroblast formation and collagen synthesis (25). In addition, $\beta$-adrenergic receptor agonists, which stimulate cAMP production, attenuate the fibroblast-mediated contraction of collagen gels (26). Nonetheless, in hepatic stem cells, the role of cAMP in TGF- $\beta$-induced FN expression remains undefined. The present study indicates that when WB cells are exposed to TGF- $\beta$ for $4 \mathrm{~h}$, the expression of cAMP in cytoplasm and nucleus increases significantly and peaks at $8 \mathrm{~h}$, especially in the cytoplasm. After treatment with TGF- $\beta$ for $24 \mathrm{~h}$, the expression of cAMP gradually decreased in WB cells. The process of cAMP alteration induced by TGF- $\beta$ in WB cells showed a pattern similar to that of FN. These findings indicate that cAMP may be involved in the TGF- $\beta$ induced up-regulation of FN. It is well known that the activa- 
tion of cAMP could result in the phosphorylation of cAMP response element binding protein (CREB), a transcription factor known for its ability to stimulate FN expression (27). Thus, it is possible that TGF- $\beta$-induced up-regulation of FN occurs in part through the CAMP-CREB pathway. However, the detailed roles of cAMP in TGF- $\beta$-induced up-regulation

\section{References}

1. Taub R. Liver regeneration: from myth to mechanism. Nat Rev Mol Cell Biol 2004; 5: 836-847.

2. Lowes KN, Croager EJ, Olynyk JK, Abraham LJ, Yeoh GC. Oval cell-mediated liver regeneration: Role of cytokines and growth factors. J Gastroenterol Hepatol 2003; 18: 4-12.

3. Walkup MH, Gerber DA. Hepatic stem cells: in search of. Stem Cells 2006; 24: 1833-1840.

4. Friedman SL. Mechanisms of hepatic fibrogenesis. Gastroenterology 2008; 134: 1655-1669.

5. Gressner AM, Weiskirchen R, Breitkopf K, Dooley S. Roles of TGF-beta in hepatic fibrosis. Front Biosci 2002; 7: d793d807.

6. Shi Y, Massague J. Mechanisms of TGF-beta signaling from cell membrane to the nucleus. Cell 2003; 113: 685-700.

7. Wells RG. Fibrogenesis. V. TGF-beta signaling pathways. Am J Physiol Gastrointest Liver Physiol 2000; 279: G845G850.

8. Thorgeirsson SS, Grisham JW. Overview of recent experimental studies on liver stem cells. Semin Liver Dis 2003; 23: 303-312.

9. Tsao MS, Smith JD, Nelson KG, Grisham JW. A diploid epithelial cell line from normal adult rat liver with phenotypic properties of 'oval' cells. Exp Cell Res 1984; 154: 38-52.

10. Hynes R. Molecular biology of fibronectin. Annu Rev Cell Biol 1985; 1: 67-90.

11. Kornblihtt AR, Pesce CG, Alonso CR, Cramer P, Srebrow A, Werbajh $\mathrm{S}$, et al. The fibronectin gene as a model for splicing and transcription studies. FASEB J 1996; 10: 248-257.

12. Border WA, Noble NA. Transforming growth factor beta in tissue fibrosis. N Engl J Med 1994; 331: 1286-1292.

13. Friedman SL. Cytokines and fibrogenesis. Semin Liver Dis 1999; 19: 129-140.

14. Gressner AM, Weiskirchen R. Modern pathogenetic concepts of liver fibrosis suggest stellate cells and TGF-beta as major players and therapeutic targets. J Cell Mol Med 2006; 10: 76-99.

15. $\mathrm{Ha} \mathrm{H}, \mathrm{Yu} M R$, Lee HB. High glucose-induced PKC activation mediates TGF-beta 1 and fibronectin synthesis by peritoneal mesothelial cells. Kidney Int 2001; 59: 463-470.

16. Kitamura Y, Ninomiya $\mathrm{H}$. Smad expression of hepatic stellate cells in liver cirrhosis in vivo and hepatic stellate cell line in vitro. Pathol Int 2003; 53: 18-26.

17. Schnur J, Olah J, Szepesi A, Nagy P, Thorgeirsson SS. Thioacetamide-induced hepatic fibrosis in transforming growth factor beta-1 transgenic mice. Eur J Gastroenterol of FN in hepatic stem-like cells merit further investigation.

The present study demonstrated for the first time that TGF- $\beta$ is involved in the fibrogenic process in hepatic stemlike cells through up-regulation of $\mathrm{FN}$ expression, and the mechanisms underlying this process seem to be associated with the activation of cAMP and Smad pathways.
Hepatol 2004; 16: 127-133.

18. Yang YC, Piek E, Zavadil J, Liang D, Xie D, Heyer J, et al. Hierarchical model of gene regulation by transforming growth factor beta. Proc Natl Acad Sci U S A 2003; 100: 10269-10274.

19. Zhao C, Chen W, Yang L, Chen L, Stimpson SA, Diehl AM. PPARgamma agonists prevent TGFbeta1/Smad3-signaling in human hepatic stellate cells. Biochem Biophys Res Commun 2006; 350: 385-391.

20. Bitzer M, von Gersdorff G, Liang D, Dominguez-Rosales A, Beg $A A$, Rojkind $M$, et al. A mechanism of suppression of TGF-beta/SMAD signaling by NF-kappa B/RelA. Genes Dev 2000; 14: 187-197.

21. Tahashi Y, Matsuzaki K, Date M, Yoshida K, Furukawa F, Sugano $Y$, et al. Differential regulation of TGF-beta signal in hepatic stellate cells between acute and chronic rat liver injury. Hepatology 2002; 35: 49-61.

22. Dooley S, Delvoux B, Lahme B, Mangasser-Stephan K, Gressner AM. Modulation of transforming growth factor beta response and signaling during transdifferentiation of rat hepatic stellate cells to myofibroblasts. Hepatology 2000; 31 : 1094-1106.

23. Mori Y, Chen SJ, Varga J. Expression and regulation of intracellular SMAD signaling in scleroderma skin fibroblasts. Arthritis Rheum 2003; 48: 1964-1978.

24. Takahashi H, Honma M, Miyauchi Y, Nakamura S, IshidaYamamoto A, lizuka H. Cyclic AMP differentially regulates cell proliferation of normal human keratinocytes through ERK activation depending on the expression pattern of BRaf. Arch Dermatol Res 2004; 296: 74-82.

25. Swaney JS, Roth DM, Olson ER, Naugle JE, Meszaros JG, Insel PA. Inhibition of cardiac myofibroblast formation and collagen synthesis by activation and overexpression of adenylyl cyclase. Proc Natl Acad Sci U S A 2005; 102: 437442.

26. Mio T, Adachi Y, Carnevali S, Romberger DJ, Spurzem JR, Rennard SI. Beta-adrenergic agonists attenuate fibroblastmediated contraction of released collagen gels. Am J Physiol 1996; 270: L829-L835.

27. Ramirez A, Ramadan B, Ritzenthaler JD, Rivera HN, Jones DP, Roman J. Extracellular cysteine/cystine redox potential controls lung fibroblast proliferation and matrix expression through upregulation of transforming growth factor-beta. Am J Physiol Lung Cell Mol Physiol 2007; 293: L972-L981. 